\title{
From the handling of an outbreak by an unknown pathogen in Wuhan to the preparedness and response in the face of the emergence of Covid-19 in Mexico
}

\author{
Eduardo López-Ortiz, ${ }^{1}$ Geovani López-Ortiz, ${ }^{1}$ Indira R. Mendiola-Pastrana, ${ }^{1}$ Juan J. Mazón-Ramírez and \\ José A. Díaz-Quiñonez²* \\ ${ }^{1}$ Family Medicine Subdivision; ${ }^{2}$ Postgraduate Studies Division. Universidad Nacional Autónoma de México, Faculty of Medicine, Mexico City, Mexico
}

\begin{abstract}
On December 31, 2019, the Chinese health authorities informed the international community, through the mechanisms established by the World Health Organization (WHO), of a pneumonia epidemic of unknown etiology in Wuhan, Hubei Province. The first cases were reported early in that month and were linked to a history of having visited a market where food and live animals are sold. On January 7, 2020, isolation and identification of the culprit pathogen was achieved using next-generation sequencing, while the number of affected subjects continued to rise. The publication of full-genomes of the newly identified coronavirus (initially called 2019-nCoV, now called SARS-CoV2) in public and private databases, of standardized diagnostic protocols and of the clinical-epidemiological information generated will allow addressing the Public Health Emergency of International Concern (PHEIC), declared on January 30 by the WHO. With this document, we intend to contribute to the characterization of the pneumonia epidemic, now designated coronavirus disease (Covid-19) review the strengths Mexico has in the global health concert and invite health professionals to join the preparedness and response activities in the face of this emergency.
\end{abstract}

KEY WORDS: New coronavirus. SARS-CoV2. Covid-19. Mexico.

\section{De la atención de un brote por un patógeno desconocido en Wuhan hasta la preparación y respuesta ante la posible emergencia del 2019-nCoV en México}

\section{Resumen}

El 31 de diciembre de 2019, las autoridades chinas de salud informaron a la comunidad internacional, a través de los mecanismos establecidos por la Organización Mundial de la Salud (OMS), de una epidemia de neumonía con etiología desconocida en Wuhan, provincia de Hubei. Los primeros casos se notificaron a inicios de ese mes y se vincularon al antecedente de visitar un mercado de comida y animales vivos. El 7 de enero de 2020 se logró el aislamiento y reconocimiento del patógeno responsable mediante secuenciación de siguiente generación, mientras el número de afectados continuaba en ascenso. La publicación de genomas completos del nuevo coronavirus identificado (inicialmente denominado 2019-nCoV, ahora designado SARS-CoV2) en bases de datos públicas y privadas, de protocolos diagnósticos estandarizados y de la información clínica epidemiológica generada permitirá atender la Emergencia de Salud Pública de Importancia Internacional (ESPII) declarada el 30 de enero por la OMS. Con este documento pretendemos aportar a la caracterización de la epidemia de neumonía, ahora llamada enfermedad por coronavirus (Covid-19), revisar las fortalezas que tiene México en el concierto de la salud global e invitar a los profesionales de la salud a incorporarse a las actividades de preparación y respuesta ante esta emergencia.

PALABRAS CLAVE: Nuevo coronavirus. SARS-CoV2. Covid-19. México. 


\section{Characterization of the pneumonia epidemic of unknown etiology}

Coronaviruses belong to the Coronaviridae family and are divided in four genera: alpha, beta, gamma and delta. The former two have the ability to infect mammals, while gamma and delta mainly infect birds, with some potential to infect mammals. ${ }^{1}$

Alpha and beta coronaviruses usually trigger respiratory symptoms in humans and gastrointestinal manifestations in other mammals. Almost all coronaviruses that have affected humans appear to come from bats. ${ }^{1,2}$

Coronavirus particles measure around $160 \mathrm{~nm}$ and their genetic material is contained in a $27-$ to $32-\mathrm{kb}$ ribonucleic acid strand. The 5' terminus encodes 16 non-structural proteins related to transcription and replication processes, while the 3 ' terminus encodes membrane, spike, nucleocapsid and envelope structural proteins.

Viral pathogenicity depends, to a large extent, on the type of receptor and the organs where the virus is expressed. Regarding the coronavirus responsible for severe acute respiratory syndrome (SARS-CoV) and SARS-CoV2, the receptor is angiotensin converting enzyme 2 and other proteases that are widely distributed in lung tissues. ${ }^{3-5}$

The report of the first cases of this epidemic can be traced to December 8, 2019. From the clinical molecular analysis of samples obtained from lung tissue, nasopharyngeal smear and blood from 42 patients who had respiratory symptoms and shared a history of having visited an animal market, 15 positive results were obtained identifying a coronavirus that had not been previously observed, so far named 2019-nCoV. 2,6

Early recognition of the pathogen as a coronavirus with similarities to SARS-CoV (microscopic characteristics, previous history of contact with animals, respiratory symptoms), the causative agent of severe acute respiratory syndrome (SARS), facilitated the definition of the surveillance system (the same that was used during the 2003 outbreak, responsible for more than 8000 cases in 26 countries). 6,7

The operational definition that was used at the beginning of the outbreak in Wuhan was based on the proposals for surveillance and the report of the 2003 and 2012 outbreaks and included the presence of four criteria: fever (quantified or not), radiological evidence of pulmonary involvement, low leukocyte or lymphocyte count and no improvement after three days of antibiotic treatment, or presence of the first three and a history of contact in the Wuhan market. . $^{8-10}$

On December 31, health authorities in China reported on the outbreak to the international community through the WHO, making public the preliminary epidemiological clinical information., 8,11,12

On January 1, 2020, Chinese health authorities closed the market associated with the outbreak to study and identify the source of contagion, which continued to be unknown. ${ }^{6}$

On January 7 , while the number of those affected continued on the rise, health authorities in China managed to identify the pathogen, an information that was released days after the first death, reported on January 9 , 2020. On January 12, the genomic sequence of the new pathogen was shared, followed by others deposited on the Genbank platforms and on GISAID (Global Initiative on Sharing All Influenza Data). It was the beginning for the use of standardized virus detection protocols and thereby, of the response from different sectors. ${ }^{13-16}$

On January 13 and 15, the first imported cases were reported in Thailand and Japan, respectively; gradually, the outbreak reached other territories. ${ }^{17}$ Chinese authorities decided to place infrared thermometers in airports and bus and railway stations.

Since January 21 , the WHO started publishing reports on the situation in affected countries. Among the actions of response by health authorities in affected countries, active search for cases and close follow-up of contacts was requested by WHO. ${ }^{18}$ On that same date, a risk analysis of viral dispersion was published, and places where the virus was more likely to spread to were alerted, with these calculations being replicated later with different methodologies. ${ }^{19-22}$

On January 23, phylodynamic analyses from 23 sequences were reported to show no evidence of an intermediate reservoir between the source of infection and humans. Mathematical estimates calculated the size of the outbreak to be approximately 4000 cases, a figure that suggested that the transmission chains were maintained by cases with not too severe symptoms that not seeking medical help. ${ }^{23,24}$

On January 26, evidence of transmission among humans was strengthened with one of the cases in Vietnam.

On January 30, the WHO announced the situation as a new Public Health Emergency of International Concern (PHEIC). In the report, special emphasis was made on strengthening technical and material supply capacities in laboratories and health infrastructure. ${ }^{13,18,25} \mathrm{~A}$ PHEIC is an event that represents the risk of international 


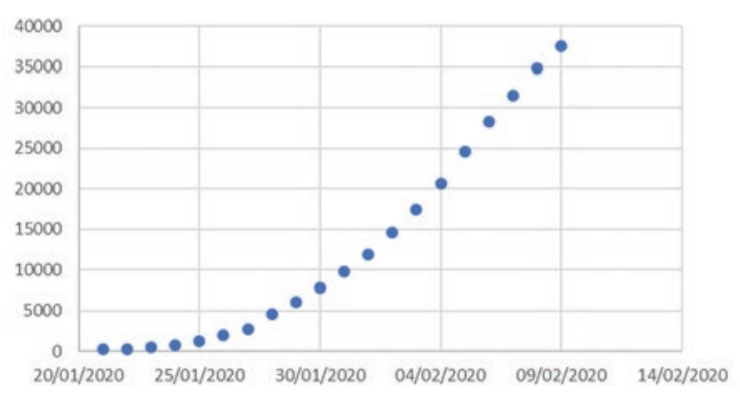

Figure 1. Accumulated cases of Covid-19 since the World Health Organization started issuing daily reports.

spread of a disease, which requires a coordinated response; the definition assumes that the situation is serious, sudden, unusual and unexpected. ${ }^{26,27}$

As it has occurred with other PHEICs, the operational definition has been dynamic. On January 18, a history of having visited Wuhan (regardless of having visited the market, which was closed on January 1) or contact with Wuhan patients who had had respiratory symptoms within the previous 14 days was included. For the confirmation of cases, using some molecular technique is necessary: 8,14

- Polymerase chain reaction aimed at identifying the $1 \mathrm{a}$ or $1 \mathrm{~b}$ reading frame that codes for viral nucleocapsid protein.

- Isolation of viruses.

- Findings of viral genetic information that relates the case to other sequences.

In the January 31 report, the number of confirmed cases had exceeded the figures reported for the outbreak of SARS in 2003 (Fig. 1). Of the 106 confirmed cases outside China, seven were reported to be asymptomatic. As of February 1, 2020, the operational definition for the outbreak defines as suspicious any patient with severe acute respiratory infection with a history of fever and cough that requires in-hospital care and whose etiology cannot be explained, in addition to the following:28

- Having traveled to or lived in Wuhan within 14 days prior to the onset of symptoms.

- Being a health worker whose activities are carried out in centers where people with respiratory diseases are treated, regardless of his/her history of travels or residence.

That day, France was reported to have diagnosed the first health worker outside China, in addition to information from Germany and Japan being compiled supporting the existence of transmission among humans. By February 5, Belgium joined the list of countries with confirmed cases. The WHO designated the disease as
Covid-19 (acronym for Coronavirus disease-2019) and launched a USD \$ 675-million preparedness and response plan as a mechanism to prepare countries lacking the necessary infrastructure to face the emergency. ${ }^{29}$

On February 6, 72 WHO member states were reported to have implemented travel restrictions. Of note, only $32 \%$ of them officially notified the WHO. ${ }^{30}$

By February 8, with 24 affected countries, the WHO response included collaboration with various stakeholders of society, from specific sectors such as financial, agricultural, touristic and academic entities to the general public, a task in which the role of social networks has been central. ${ }^{31,32}$

On February 9 , in its daily report, the WHO announced that projects aimed at updating health personnel protection measures, a field data collection tool and translation of available materials on the outbreak into several languages were underway. ${ }^{33}$

Epidemiological estimators for Covid-19 have varied as new information has become available; however, the basic reproduction index calculations remain positive, with incubation periods ranging from two to 14 days. Male adults remain with the highest proportion among diagnosed cases (71\%); elderly individuals with comorbidities represent the population group that is most susceptible to die from the infection, with median age at diagnosis being around 45 years. , $^{8,34-37}$

\section{Preparedness and response in Mexico}

The Ministry of Health of Mexico has made publicly available dissemination materials with general information on the situation of the Covid-19 outbreak since its inception. On January 30, it issued a preventive notice about travelling to the Hubei Province in China, and every day it publishes a report with verified data from official sources..$^{38}$

In addition, the National Epidemiological Surveillance System developed the Standardized guidelines for epidemiological and laboratory surveillance of 2019-nCoV-related disease, a document that establishes operational definitions, handling of samples, prevention measures and risk control, in addition to providing a diagnostic algorithm in the face of the risk of arrival of the emerging pathogen. ${ }^{39}$ This document considers different areas of epidemiological surveillance in the event of an international emergency, and as an appendix it presents a special form for the study of cases, follow-up of contacts, recommendations for international points of entry and a line of action for health workers who handle a suspicious case. 
The importance to continue with the updates of this guideline -the first one was on February 7, 2020- lies in ensuring the rapid detection of imported cases and thus avoiding the generation of secondary transmission chains. ${ }^{39}$

In Mexico, a person of any age who has an acute respiratory illness and who has a history of travel to or stay in the Hubei Province, China, or who has been in contact with a confirmed case or an individual under investigation for up to 14 days prior to the onset of symptoms is considered a Covid-19 suspicious case. Confirmation is established with standardized methods by the "Dr. Manuel Martínez Báez" Epidemiological Diagnostic and Reference Institute (InDRE - Instituto de Diagnóstico y Referencia Epidemiológicos).

The investigation of suspect cases must be carried out in accordance with the standard protection measures and based on the mechanism of transmission (by droplet and contact).

- Standard precautions: handwashing (soap and water) or hand hygiene (alcohol gel at concentrations higher than $70 \%$ at the five moments defined by the WHO), use of gloves, use of facemask with facial protection and waterproof gown if there is the risk of splashing to the eyes and face, disposal of contaminated clothing in a red bag, use of rigid containers for sharps and never re-cover the needles once used.

- Precautions for transmission by droplets: keep a distance of one meter with the patient, keep the door closed during patient care, monitor visitors, personalized use of medical equipment such as stethoscope, thermometers or blood pressure cuffs; if this is not possible, clean and disinfect between each patient with $70 \%$ ethyl alcohol; assignment of a single room for the suspected case or isolation of the cohort, transfer of the patient only for special situations and notification to the care team about these measures.

- Precautions for aerosol transmission: use of N95 facemask in procedures that generate aerosols such as aspirations, intubations, bronchoscopies and cardiopulmonary resuscitation.

Working lines were established for health personnel in contact with suspicious cases, with differences for the levels of care existing in Mexico.

Upon identification of a case that meets the travel history or risk contact, the first measure for the primary care physician will be to provide a surgical mask to the patient. From that moment on, the doctor will assess the patient in an isolated space with protective measures such as disposable gown, glasses and gloves, and will decide if the case meets the operational definition; if the case is positive, the doctor will use a N95 mask for protection and will take samples and notify the corresponding epidemiological instance. Should hospitalization be necessary, the patient should be sent to the appropriate level, monitored by the epidemiology area .

At secondary and tertiary care it is assumed that patients will arrive with data consistent with respiratory distress, in which case the workflow would be similar to that of primary care. At these levels, isolated beds for patients will be necessary, as well as the use of specialized protective equipment for health personnel, such as facemask, disposable gown and protective goggles, the latter because there is evidence of potential transmission by that route. ${ }^{40}$ The epidemiology team is established as a link to provide information on the follow-up of each case.

The samples for Covid-19 diagnosis are nasopharyngeal and pharyngeal exudate taken with dacron or rayon swabs, with the tubes being transported together (in viral medium at $4{ }^{\circ} \mathrm{C}$ ) to increase viral load. If the patient is intubated, bronchoalveolar lavage fluid should be obtained (at least $1 \mathrm{~mL}$ of aspirate and $1 \mathrm{~mL}$ of transport medium is required) and, in case of death, lung biopsy $\left(2 \mathrm{~cm}^{3}\right)$. The samples must be obtained during the first five days of clinical presentation and be transported in a triple packaging system, in accordance with established guidelines. ${ }^{39}$ If the case is confirmed, patient isolation is recommended for up to 14 days after the resolution of clinical manifestations. The confirmation algorithm considers differential diagnosis with other respiratory pathogens such as influenza, parainfluenza, adenovirus, respiratory syncytial virus, Middle East respiratory syndrome coronavirus (MERS-CoV), SARS-CoV and other coronaviruses. ${ }^{41}$

Current situation with Covid-19 is of an uncertain outlook. Ignorance on the source of dispersion, in addition to not having a specific treatment or preventive vaccine, puts us in a challenging scenario where collaboration, information exchange and transparency between different sectors of society are valuable means of protection. ${ }^{42,43}$

During 2019, a total of 60 municipalities in Mexico (with 32,851,129 inhabitants) received 15,072,653 visitors by air from countries that have Covid-19 confirmed cases so far (Fig. 2). This puts into perspective the connectivity of the different regions of the country, 


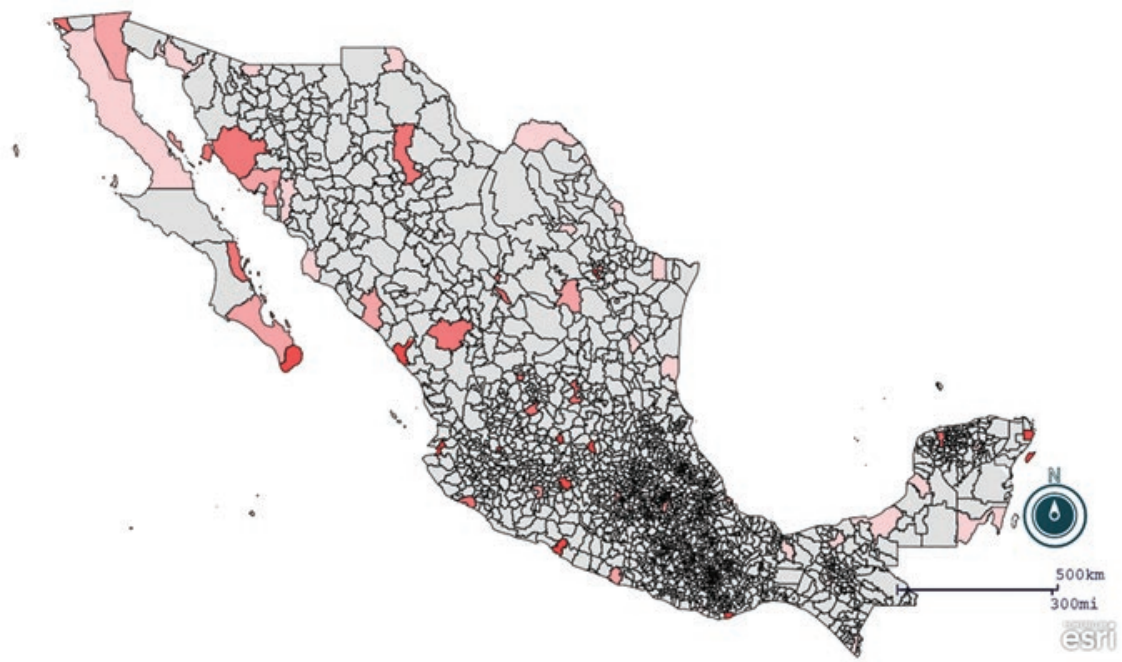

Figure 2. Choropleth map representing the number of visitors from countries with Covid-19 confirmed cases, by municipality, until November 2019. Data from the Ministry of Foreign Affairs.

mostly densely populated territories. These destinations would represent the areas of highest risk for arrival of the pathogen.

\section{Considerations for health workers}

Previous epidemics have left useful lessons to mankind. At this moment of the Covid-19 outbreak, effective dissemination of information is key for transmission chains to be cut. The WHO has dedicated a public site to the dissemination of courses for continuous learning that contains updating modules, at the level of response in both public and clinical and laboratory health. ${ }^{44-47}$

In a coordinated way, the academy and private institutions have created scientific discussion forums, visualization platforms and dissemination of information on the outbreak that allow real-time traceability of events. Although they will not always coincide with official figures, these tools represent a modality for the study of the outbreak that the public health sector had not used ever before. . $^{14,46,48,49}$

\section{Conclusions}

The close dynamics we have with other species has caused the emergence of epidemics related to unknown pathogens or that we considered under control. In terms of global health, it is difficult to define nationalities or territories. The Covid-19 outbreak will leave lessons on the power of collaboration before a PHEIC, regardless of how many countries it affects. In Mexico we must learn from the lessons and strategies of the countries that have been affected. New knowledge is generated every day that, if used properly, will allow us to face the introduction of this and other emerging diseases.

\section{Conflict of interests}

None

\section{Funding}

This investigation has not received any specific grant from public or commercial sector agencies, and was carried out without a profit motive.

\section{References}

1. Cui J, Li F, Shi ZL. Origin and evolution of pathogenic coronaviruses. Nat Rev Microbiol. 2019;17(3):181-92. DOI: 10.1038/s41579-018-0118-9

2. Lu R, Zhao X, Li J, Niu P, Yang B, Wu H, et al. Genomic characterisation and epidemiology of 2019 novel coronavirus: implications for virus origins and receptor binding. Lancet. 2020;6736(20):1-10. Disponible en: http:// www.ncbi.nlm.nih.gov/pubmed/32007145

3. Hoffmann M, Kleine-Weber H, Krüger N, Müller M. The novel coronavirus 2019 (2019-nCoV) uses the SARS-coronavirus receptor ACE2 and the cellular protease TMPRSS2 for entry into target cells. bioRxiv. 2020 Jan 31. DOI: 10.1101/2020.01.31.929042.

4. Wan Y, Shang J, Graham R, Baric RS, Li F. Receptor recognition by novel coronavirus from Wuhan: an analysis based on decade-long structural studies of SARS. J Virol. 2020 Jan 29. pii: JVI.00127-20. DOI: 10.1128/JVI.00127-20. [Epub ahead of print]. Disponible en: http://www. ncbi.nlm.nih.gov/pubmed/31996437

5. Ramaiah A, Arumugaswami V. Insights into cross-species evolution of novel human coronavirus 2019-nCoV and defining immune determinants for vaccine development. bioRxiv. 2020 Feb 4. DOI: 10.1101/2020.01.29.925867

6. Lu H, Stratton CW, Tang Y. Outbreak of pneumonia of unknown etiology in Wuhan China: the mystery and the miracle. J Med Virol. 2020;jmv.25678. Disponible en: https://onlinelibrary.wiley.com/doi/abs/10.1002/jmv.25678

7. World Health Organization. SARS (severe acute respiratory syndrome) [Consultado 2020 Feb 1. Disponible en: https://www.who.int/ith/diseases/ sars/en

8. Li Q, Guan X, Wu P, Wang X, Zhou L, Tong Y, et al. Early transmission dynamics in Wuhan, China, of novel coronavirus-infected pneumonia. N Engl J Med. 2020;1-9. Disponible en: http://www.ncbi.nlm.nih.gov/ pubmed/31995857 
9. World Health Organization. WHO guidelines for the global surveillance of severe acute respiratory syndrome (SARS). Updated recommendations, October 2004. Disponible en https://www.who.int/csr/resources/ publications/WHO_CDS_CSR_ARO_2004_1/en

10. World Health Organization. Middle East respiratory syndrome case definition for reporting to WHO. WHO 2017 Jul 26. Disponible en: https:// www.who.int/csr/disease/coronavirus_infections/case_definition/ en/\%0Ahttp://www.who.int/csr/disease/coronavirus_infections/mers-interim-case-definition.pdf?ua $=1$

11. World Health Organization. Novel coronavirus 2019. [Consultado 2020 Feb 1. Disponible en: https://www.who.int/emergencies/diseases/ novel-coronavirus-2019

12. World Health Organization. About IHR. WHO; 2017. [Consultado 2019 Ago 20. Disponible en: https://www.who.int/ihr/about/en

13. Corman VM, Landt $\mathrm{O}$, Kaiser M, Molenkamp R, Meijer A, Chu DK, et al. Detection of 2019 novel coronavirus (2019-nCoV) by real-time RT-PCR Eurosurveillance. 2020;25(3):2000045. Disponible en: https://www.eurosurveillance.org/content/10.2807/1560-7917.ES.2020.25.3.2000045

14. Nextstrain [sitio web]. Real-time tracking of pathogen evolution. [Consultado 2020 Feb 8. Disponible en: https://nextstrain.org

15. Cohen J. New coronavirus threat galvanizes scientists. Science. 2020;367(6477):492-493.

16. Du Toit A. Outbreak of a novel coronavirus. Nat Rev Microbiol. 2020;41579. Disponible en: http://dx.doi.org/10.1038/s41579-020-0332-0

17. Phan LT, Nguyen T V, Luong QC, Nguyen T V, Nguyen HT, Le HQ, et al. Importation and human-to-human transmission of a novel coronavirus in Vietnam. N Engl J Med. 2020 Jan 28. [Epub ahead of print]. DOI: 10.1056/NEJMc2001272.

18. World Health Organization. Novel coronavirus (2019-nCoV). Situation report 1. 21 January 2020. WHO; 2020. Disponible en: https://www.who. int/docs/default-source/coronaviruse/situation-reports/20200121-sitrep-12019-ncov.pdf?sfvrsn=20a99c10_4

19. Chinazzi M, Davis JT, Gioannini C, Pastore A, Rossi L, Xiong X, et al. Preliminary assessment of the international spreading risk associated with the 2019 novel coronavirus (2019-nCoV) outbreak in Wuhan city. Center for Inference \& Dynamics of Infectious Diseases [sitio web]; 2020. Disponible en: http://www.cidid.org/publications-1/2020/1/20/preliminary-assessment-of-the-international-spreading-risk-associated-with-the-2019-novel-coronavirus-2019-ncov-outbreak-in-wuhan-city

20. Bogoch II, Watts A, Thomas-Bachli A, Huber C, Kraemer MUG, Khan K. Potential for global spread of a novel coronavirus from China. J Travel Med. 2020 Jan 27:53(9):1689-99. DOI: 10.1093/itm/taaa011/5716260

21. Isaac I. Bogoch, Alexander Watts, Andrea Thomas-Bachli, Carmen Huber, Moritz U.G. Kraemer KK. Pneumonia of Unknown Etiology in Wuhan, China: Potential for International Spread Via Commercial Air Travel. J Travel Med. 2020

22. Wu JT, Leung K, Leung GM. Nowcasting and forecasting the potentia domestic and international spread of the 2019-nCoV outbreak originating in Wuhan, China: a modelling study. Lancet. 2020 Jan;6736(20). Disponible en: 10.1016/S0140-6736(20)30260-9

23. World Health Organization. Novel Coronavirus (2019-nCoV). Situation report-3. [Consultado 2020 Feb 8. Disponible en: https://www.who.int/ docs/default-source/ coronaviruse/situation-reports/ 20200123-sitrep-32019-ncov. pdf?sfvrsn=d6d23643 8

24. Imai N, Dorigatti I, Cori A, Riley S, Ferguson NM. Estimating the potential total number of novel coronavirus cases in Wuhan City, China. Imp Coll London. 2020 Jan 17:1-4. Disponible en: https://www.imperial.ac.uk media/imperial-college/medicine/ sph/ide/gida-fellowships/ 2019-nCoV-outbreak- report-17-01-2020.pdf

25. World Health Organization. Statement on the second meeting of the International Health Regulations (2005) Emergency Committee regarding the outbreak of novel coronavirus (2019-nCoV). [Consultado 2020 Feb 1. Disponible en: https://www.who.int/ news-room/detail/ 30-01-2020-statement-on-the-second-meeting-of-the-international-health-regulations-(2005)-emergency-committee-regarding-the-outbreak-of-novel-coronavirus -(2019-ncov)

26. World Health Organization. What are the International Health Regulations and Emergency Committees? [Consultado 2020 Jan 31. Disponible en: https://www.who.int/news-room/q-a-detail/what-are-the-international -health-regulations-and-emergency-committees

27. Simón-Soria F. Public Health Emergencies of International Concern. An opportunity to improve global health security. Enferm Infecc Microbiol Clin. 2016;34(4):219-221.
28. World Health Organization. Surveillance case definitions for human infection with novel coronavirus (nCoV). WHO; 2020. Disponible en: https:// www.who.int/publications-detail/surveillance-case-definitions-for-human-infection-with-novel-coronavirus-(ncov)

29. World Health Organization. US\$675 million needed for new coronavirus preparedness and response global plan. [Consultado 2020 Feb 8. Disponible en: https://www.who.int/ news-room/detail/05-02-2020-us-675million-needed-for-new-coronavirus-preparedness-and-response-global-plan

30. World Health Organization. Novel coronavirus(2019-nCoV). Situation report-17. [Consultado 2020 Feb 9. Disponible en: https://www.who.int/ docs/ default-source/coronaviruse/ situation-reports/20200206 -sitrep-17ncov.pdf? sfvrsn=17f0dca_4

31. World Health Organization. Novel coronavirus (2019-nCoV). Situation report 11. WHO Bull. 2020 Jan 31:1-7.

32. Strzelecki A. Infodemiological study using Google trends on coronavirus epidemic in Wuhan, China. 2020. arXiv. 2001:11021. Disponible en: http://arxiv.org/abs/2001.11021

33. World Health Organization. Novel coronavirus (2019-nCov). Situation report 20. WHO; 2020. p. 7 [Consultado 2020 Feb 9. Disponible en: https://www.who.int/docs/default-source/coronaviruse/situation-reports/20200209-sitrep-20-ncov.pdf?sfvrsn=6f80d1b9_4

34. Tao Liu, Jianxiong Hu, Min Kang, Lifeng Lin, Haojie Zhong, Jianpeng Xiao GH. Transmission dynamics of 2019 novel coronavirus (2019-nCoV). bioRxiv. 2020;21(1):1-9. DOI: https://doi.org/10.1101/2020. 01.25.919787

35. Read JM, Bridgen JR, Cummings DA, Ho A, Jewell CP. Novel coronavirus 2019-nCoV: early estimation of epidemiological parameters and epidemic predictions. medRxiv. 2020 Dec 28. DOI: 10.1101/ 2020.01.23.20018549

36. Worldometer [sito web]. Wuhan Coronavirus outbreak. [Consultado 2020 Feb 9. Disponible en: https://www.worldometers.info/coronavirus

37. Huang C, Wang Y, Li X, Ren L, Zhao J, Hu Y, et al. Clinical features of patients infected with 2019 novel coronavirus in Wuhan, China. Lancet. 2020;6736(20):1-10. Disponible en: https://doi.org/10.1016/S0140$6736(20) 30183-5$

38. Secretaría de Salud. Nuevo coronavirus 2019 nCoV-Comunicado técnico diario. [Consultado 2020 Feb 1. Disponible en: https://www.gob.mx/salud/ documentos/nuevo-coronavirus-2019-ncov-comunicado-tecnico-diario

39. Secretaría de Salud. Lineamiento estandarizado para la vigilancia epidemiológica y por laboratorio de enfermedad por 2019-nCov. Disponible en: http://cvoed.imss.gob.mx/ secretaria-de-salud-lineamiento-estandarizado-para-la-vigilancia-epidemiologica-y-por-laboratorio-de-enfermedad-por-201-ncov/\# iLightbox[gallery2287]/0

40. Dirección General de Epidemiológica S de S. Lineamiento estandarizado para la vigilancia epidemiología y por laboratorio de enfermedad por 2019nCov_7_2_2020.2020.

41. Lu C, Liu X, Jia Z. 2019-nCoV transmission through the ocular surface must not be ignored. Lancet. 2020 Feb 6. DOI: 10.1016/S0140-6736(20)30313-5

42. Secretaría de Salud. Lineamientos para la vigilancia por laboratorio del dengue y otras arbovirosis. México: SSa; 2017. p. 12-95.

43. World Health Organization. National capacities review tool for a novel coronavirus (nCoV). WHO; 2020. Disponible en: https://www.who.int/ publications-detail/national-capacities-review-tool-for-a-novel-coronavirus-(ncov)

44. World Health Organization. Risk communication and community engagement (RCCE) readiness and response to the 2019 novel. WHO; 2020 Jan 26. Disponible en: https://www.who.int/publications-detail/ risk-communication-and-community-engagement-readiness-and-initialresponse-for-novel-coronaviruses-(-ncov)

45. OpenWHO [sitio web]. Trainings for current outbreaks. Covel coronavirus (2019-nCoV). [Consultado 2020 Feb 9. Disponible en: https://openwho.org

46. World Health Organization. Critical care severe acute respiratory infection training. [Consultado 2020 Feb 9. Disponible en: https://openwho. org/courses/ severe-acute-respiratory-infection

47. World Health Organization. Technical guidance novel coronavirus 2019 [Consultado 2020 Feb 9. Disponible en: https://www.who.int/emergencies/ diseases/novel-coronavirus-2019/ technical-guidance

48. Rambaut A. Phylogenetic analysis of $23 \mathrm{nCoV}-2019$ genomes. Virological [Internet]. 2020 Ene 23. Disponible en: http://virological.org/t/phylogenetic-analysis-of-23-ncov-2019-genomes-2020-01-23/335

49. Engineering JHWS of. Coronavirus 2019-nCoV [Internet]. 2020 [cited 2020 Feb 1]. Available from: https://gisanddata.maps.arcgis.com/apps/ opsdashboard/index.html\#/bda7594740fd40299423467b48e9ecf6 